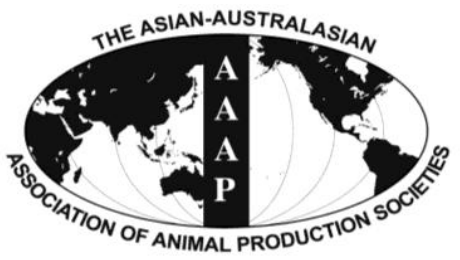

Asian Australas. J. Anim. Sci.

Vol. 26, No. 9 : 1218-1228 September 2013

http://dx.doi.org/10.5713/ajas.2013.13058

www.ajas.info

pISSN 1011-2367 elSSN 1976-5517

\title{
Identification of Stearoyl-CoA Desaturase (SCD) Gene Interactions in Korean Native Cattle Based on the Multifactor-dimensionality Reduction Method
}

\author{
Dong-yep Oh, Me-hyun Jin', Yoon-seok Lee², Jae-jung Ha, Byung-ki Kim, \\ Jung-sou Yeo ${ }^{3}$, and Jea-young Lee ${ }^{1, *}$ \\ Livestock Research institute, Gyeongsangbuk-Do, Yeongju, Gyeongbuk, 750-871, Korea
}

\begin{abstract}
Fat quality is determined by the composition of fatty acids. Genetic relationships between this composition and single nucleotide polymorphisms (SNPs) in the stearoyl-CoA desaturase1 (SCD1) gene were examined using 513 Korean native cattle. Single and epistatic effects of 7 SNP genetic variations were investigated, and the multifactor dimensionality reduction (MDR) method was used to investigate gene interactions in terms of oleic acid (C18:1), mono-unsaturated fatty acids (MUFAs) and marbling score (MS). The g.6850+77 A>G and g.14047 C>T SNP interactions were identified as the statistically optimal combination (C18:1, MUFAs and MS permutation p-values were $0.000,0.000$ and 0.001 respectively) of two-way gene interactions. The interaction effects of g.6850+77 $\mathrm{A}>\mathrm{G}$, g.10213 $\mathrm{T}>\mathrm{C}$ and g.14047 $\mathrm{C}>\mathrm{T}$ reflected the highest training-balanced accuracy $(63.76 \%, 64.70 \%$ and $61.85 \%$ respectively) and was better than the individual effects for C18:1, MUFAs and MS. In addition, the superior genotype groups were AATTCC, AGTTCC, GGTCCC, AGTCCT, GGCCCT and AGCCTT. These results suggest that the selected SNP combination of the SCD1 gene and superior genotype groups can provide useful inferences for the improvement of the fatty acid composition in Korean native cattle. (Key Words: Korean Native Cattle, Multifactor-Dimensionality Reduction (MDR), Single Nucleotide Polymorphism (SNP), Stearoyl-CoA Desaturase1 (SCD1) Gene)
\end{abstract}

\section{INTRODUCTION}

Fat quality in beef market is determined by its fatty acid composition and fat tissue containing mono-unsaturated fatty acids (MUFAs), which have a lower melting point and thus contribute to the flavor and tenderness of beef (Miyazaki et al., 1979; Melton et al., 1982; Matsumoto et al., 2007). Oleic acid (C18:1) is one of the major MUFAs in beef fat and thought to be the source of the aroma in cooked beef (Melton et al., 1982; Mandell et al., 1998). For highquality beef, it is important to improve its fatty acid composition, particularly its $\mathrm{C} 18: 1$. In addition, the fatty

\footnotetext{
* Corresponding Author: Jea-Young Lee. Tel: +82-53-810-2326, Fax: +82-53-810-4615, E-mail: jlee@yu.ac.kr

${ }^{1}$ Department of Statistics, Yeungnam University, Gyeongsan-si, Gyeongbuk 712-749, Korea.

${ }^{2}$ Institute of Green Bio Science and Technology, Seoul National University, Kangwon-do, Pyeongchang-gun 232-916, Korea.

${ }^{3}$ School of Biotechnology, Yeungnam University, Gyeongsan-si, Gyeongbuk 712-749, Korea.

Submitted Jan. 22, 2013; Accepted Apr. 27, 2013; Revised May 26, 2013
}

acid composition is a heritable trait with heritability ranging from 0.31 to 0.73 (Inoue et al., 2008).

The stearoyl-CoA desaturase (SCD) gene, an enzyme in the chemical conversion of saturated fatty acids to unsaturated fatty acids, has been reported as a main factor for change of stearic acid (C18:0) and palmitic acid (C16:0) to $\mathrm{C} 18: 1$ on unsaturated fatty acid of $\mathrm{w}-9$; and many studies have attempted to increase unsaturated fatty acids for the improved flavor of meat and health benefits (Kuchel et al., 2004; Scollan et al., 2006; Alexander et al., 2007; Erkkila et al., 2008; Webb and O'Neill, 2008; Zhang et al., 2008). Recently, genetic relationships between the fatty acid composition of beef and multiple nucleotide sequence variants have been examined in encoding the SCD1 gene (Taniguchi et al., 2004). Three variants c.702 A<G, c.762 $\mathrm{T}<\mathrm{C}$ and c.878 $\mathrm{C}<\mathrm{T}$ in the exon 5 region have been found to be associated with the composition of unsaturated fatty acids and MUFAs in the adipose tissue of Wagyu, Canadian Holstein, Jersey breeds, Fleckvieh bulls and Korean native cattle $(\mathrm{p}<0.05)$ (Kgwatalala et al., 2007; Milanesi et al., 2008; Tsuji, 2008; Barton et al., 2010; Ohsaki et al., 2009; 
Oh et al., 2011). SNPs in the UTR region of the SCD1 gene are significantly related to carcass and beef traits without an evaluation of fatty acids in Hanwoo (Shin et al., 2006). Based on the above discussion, the SCD gene, which is closely related to $\mathrm{C} 18: 1$ as an important factor influencing the beef flavor, is considered to improve beef quality. This indicates that it is important not only to reveal the independent effect of each factor but also to analyze the combined effects. However, previous studies have paid little attention to single-factor effects and have not always considered independent and combined effects.

The multifactor dimensionality reduction (MDR) method has been employed (Ritchie et al., 2001; Chung et al., 2006) as a technique for efficiently detecting multiple genes and their interaction effects. This method is designed to address high-dimensional data and uncover complex relationships without relying on specified models fitting interactions between multiple genes (Bastione et al., 2004). With the increased availability of SNP information from an increasing number of SNPs in livestock genome databases (www.animalgenome.org) as well as human and other mammalian genomes, functional SNPs represent a better option for the simultaneous identification of several SNPs based on high-throughput tools such as DNA chips (Barendse et al., 2007).

In this study, the MDR method was used to detect superior SNP combinations influencing C18:1, MUFAs and marbling score (MS) in Korean native cattle. Given that the detection of genetic information on 15 SNPs in the intron, exon5 and 3'UTR regions of the SCD1 gene are significantly associated with fatty acid composition and MS (Oh et al., 2011), the interaction effects of SNPs in the SCD1 gene on C18:1, MUFAs and MS were examined. Here multiple SNPs were used by employing the MDR method to test the main and interaction effects of multiple SNPs on the meat quality of Korean native cattle, and a number of SNP factors believed to affect C18:1, MUFAs and MS were considered. Finally, the superior genotype groups were explored based on interactions between candidate genes.

\section{MATERIALS AND METHODS}

\section{Animals and the phenotype}

A total of 513 Korean native cattle (called Hanwoo in Korea) were bred in Gyeongsangbuk-Do, Korea. The cattle were fed according to the feeding program of each farmer $(n=14)$ and were the progeny of 18 sires. The pedigree records of these cattle were collected by the Charmpoom Hanwoo Research Institution. In general, they were weaned at 6 months of age, castrated at 6 months of age, fed growth-stage feed for 18 months, and given a highconcentration diet in the last 6 months. All were slaughtered at $941 \pm 72 \mathrm{~d}$ of age, and the marbling score was measured $24 \mathrm{~h}$ after slaughter. First, the carcass was dissected at the last rib and the first lumber vertebra according to the Animal Product Grading System of Korea. The MS was measured in the left carcass cut across the vertebra between the last thoracic vertebra and the first lumbar vertebra. The marbling degree was scored from 1 to 9 (mean $=5.43$ ) such that the higher the score, the more abundant the intramuscular fat. Genomic DNA was extracted from the longissimus muscle by using the LaboPass Tissue Mini kit (Cosmo Genetech, Seoul, Korea).

Total lipids were extracted from approximately $500 \mathrm{mg}$ of the longissimus muscle with chloroform/methanol (2/1, v/v) (Folch et al., 1957) and then methylated with sodium methylate (O'Keefe et al., 1968). They were filtered through a filter paper in a water bath $\left(40^{\circ} \mathrm{C}\right)$. The filtrate was mixed with distilled water, from which a layer of methanol and water was removed. After the removal of chloroform and lipid layers by using nitrogen gas, the sample was treated with $\mathrm{BF} 3$-methanol (14\%) and then subjected to transmethylation at $65^{\circ} \mathrm{C}$. Fatty acid contents were analyzed using gas-chromatography (PerkinElmer, Inc., Waltham, MA, USA).

\section{SNP genotyping}

Fifteen SNPs of the SCD1 gene were selected based on the reference SNP of the bovine SCD1 gene (GenBank No. AY241932) in dbSNP. Genotypes at the 15 SNPs were subjected to a preliminary analysis. Primers for their amplification and extension were designed for single-base extension (SBE) (Vreeland et al., 2002) by using forward, reverse, and extension primer sequences (Supplementary Table 1). Primer extension reactions were performed using the SNaPshot ddNTP Primer Extension Kit (Applied Biosystems, Foster City, CA, USA). For the purification of the reaction of the primer extension, mixtures containing exonuclease 1 and shrimp alkaline phosphatase were added to the reaction mixtures. Samples were cultured at $37^{\circ} \mathrm{C}$ for $1 \mathrm{~h}$ and then inactivated at $72^{\circ} \mathrm{C}$ for $15 \mathrm{~min}$. The PCR product was mixed with the Genescan 120 LIZ standard and HiDi formamide (Applied Biosystems), followed by denaturation at $95^{\circ} \mathrm{C}$ for $5 \mathrm{~min}$. Electrophoresis was performed using the ABI PRISM 3130XL Genetic Analyzer, and then the electrophoresis product was assayed using GeneMapper v.4.0 (Applied Biosystems).

\section{Linear discriminant and statistical analyses}

For 45 extreme cattle, the significance of SNPs allele frequencies between the two groups (high and low) was analyzed using the chi-square test. Those SNP alleles for which there was a significant frequency difference were included in a linear discriminant analysis to develop a function classifying animals into the two groups (Tsuji et al., 
Supplementary Table 1. The information of primer sequence about SNPs of SCD (Accession number : NM_AY241932) gene of BTA 26 in Korean native cattle

\begin{tabular}{|c|c|c|c|c|c|}
\hline$\overline{\mathrm{SNP}}$ & Region & & Sequences & Temperature & Product size \\
\hline \multirow[t]{3}{*}{ g.6850+77 A>G } & Intron & $\mathrm{F}^{1}$ & ACTCTGGCCTGAGGAAAACA & 60 & 348 \\
\hline & & $\mathrm{R}^{2}$ & CCGGAACTTAACCACAAGGA & & \\
\hline & & $E^{3}$ & GTGGCGGAATGGAGGCGATC & & \\
\hline \multirow[t]{3}{*}{ g. $8243-72 A>G$} & & $\mathrm{~F}$ & AGGCATCAGAATGGAACTGC & 60 & 401 \\
\hline & & $\mathrm{R}$ & AGACACCCTCTCAGGGGAAT & & \\
\hline & & $\mathrm{E}$ & AGCTGTGGGCTCTGGAAGAC & & \\
\hline \multirow[t]{3}{*}{ g. $8646+128 \mathrm{~A}>\mathrm{G}$} & & $\mathrm{F}$ & AGCTGGTGATGTTCCAGAGG & 60 & 390 \\
\hline & & $\mathrm{R}$ & TTTGTGCCTCTCCTCGCTAT & & \\
\hline & & $\mathrm{E}$ & AAATTACAATTTAAAACCCT & & \\
\hline \multirow[t]{3}{*}{ g. $10153 \mathrm{~A}>\mathrm{G}$} & Exon 5 & $\mathrm{~F}$ & CAGAAAATTTCCTTGCCCATT & 60 & 552 \\
\hline & & $\mathrm{R}$ & TGTTGCTTAACTTTCAAGGGTTT & & \\
\hline & & $\mathrm{E}$ & ATCCTGCCCACACTCGTGCC & & \\
\hline \multirow[t]{3}{*}{ g.10213 T>C } & & $\mathrm{F}$ & CAGAAAATTTCCTTGCCCATT & 60 & 552 \\
\hline & & $\mathrm{R}$ & TGTTGCTTAACTTTCAAGGGTTT & & \\
\hline & & $\mathrm{E}$ & TTTGCCACCTTATTCCGTTA & & \\
\hline \multirow[t]{3}{*}{ g.10329 C>T } & & $\mathrm{F}$ & CAGAAAATTTCCTTGCCCATT & 60 & 552 \\
\hline & & $\mathrm{R}$ & TGTTGCTTAACTTTCAAGGGTTT & & \\
\hline & & $\mathrm{E}$ & TCTGGTTTCCCTGGGAGCTG & & \\
\hline \multirow[t]{3}{*}{ g. $13565 \mathrm{G}>\mathrm{T}$} & 3'UTR & $\mathrm{F}$ & TTTTGTCCCTGTCACCTTCC & 60 & 425 \\
\hline & & $\mathrm{R}$ & AGGGAGCATACTGGGTGATG & & \\
\hline & & $\mathrm{E}$ & TCCAAAGCCTAGACAACCCT & & \\
\hline \multirow[t]{3}{*}{ g. $13757 \mathrm{C}>\mathrm{A}$} & & $\mathrm{F}$ & TTTTGTCCCTGTCACCTTCC & 60 & 425 \\
\hline & & $\mathrm{R}$ & AGGGAGCATACTGGGTGATG & & \\
\hline & & $\mathrm{E}$ & ACCAAACTGAAAAAACAGGT & & \\
\hline \multirow[t]{3}{*}{ g. $14047 \mathrm{C}>\mathrm{T}$} & & $\mathrm{F}$ & GTCTGCCCATCACCCAGTAT & 60 & 397 \\
\hline & & $\mathrm{R}$ & TCACCACCATACCACCAATG & & \\
\hline & & $\mathrm{E}$ & GAATTGTTTTCTTTCTTTCA & & \\
\hline \multirow[t]{3}{*}{ g. $14578 \mathrm{~A}>\mathrm{G}$} & & $\mathrm{F}$ & AGAGGGGGCTTGAAGAAGAG & 60 & 469 \\
\hline & & $\mathrm{R}$ & GCTTGCCTGTCCAGAAAAAG & & \\
\hline & & $\mathrm{E}$ & GTTGTTGGGTGTCCTGATAT & & \\
\hline \multirow[t]{3}{*}{ g. $15001 \mathrm{~A}>\mathrm{G}$} & & $\mathrm{F}$ & TGACAGAATGGTCAGGGTCA & 60 & 328 \\
\hline & & $\mathrm{R}$ & TGACTCAGGGTAGGCAGCTT & & \\
\hline & & $\mathrm{E}$ & ACTTGGCCTCCAGAGTCTCC & & \\
\hline \multirow[t]{3}{*}{ g. $15101 \mathrm{C}>\mathrm{T}$} & & $\mathrm{F}$ & TGACAGAATGGTCAGGGTCA & 60 & 328 \\
\hline & & $\mathrm{R}$ & TGACTCAGGGTAGGCAGCTT & & \\
\hline & & $\mathrm{E}$ & GCATTCGCACTCATGAGGCA & & \\
\hline \multirow[t]{3}{*}{ g. $15202 \mathrm{G}>\mathrm{A}$} & & $\mathrm{F}$ & TGACAGAATGGTCAGGGTCA & 60 & 328 \\
\hline & & $\mathrm{R}$ & TGACTCAGGGTAGGCAGCTT & & \\
\hline & & $\mathrm{E}$ & CAGAACCAGAGAGCATGCTG & & \\
\hline \multirow[t]{3}{*}{ g. $15491 \mathrm{G}>\mathrm{A}$} & & $\mathrm{F}$ & GGGAAGCACAAGAAGCAAAG & 60 & 320 \\
\hline & & $\mathrm{R}$ & CAGTGGCAGAGCATTTGGTA & & \\
\hline & & $\mathrm{E}$ & CAACACAGTCTAGGGCAGAC & & \\
\hline \multirow[t]{3}{*}{ g. $16524 \mathrm{C}>\mathrm{T}$} & & $\mathrm{F}$ & GGTAGTTTTAATTCCACAGGTCAT & 58 & 332 \\
\hline & & $\mathrm{R}$ & TCCAAAATTATTCTTAGGTCACAA & & \\
\hline & & $\mathrm{E}$ & ATGAAAAGTTCAAGAAAGCT & & \\
\hline
\end{tabular}

${ }^{1}$ Forward sequence. ${ }^{2}$ Reverse sequence. ${ }^{3}$ Extension sequence.

2008). Only the influential fragments for discrimination (F $>2.5$ ) were included in the function.

The Hardy-Weinberg equilibrium (HWE) was determined for each locus by comparing expected frequency with observed genotype frequencies by using the chi-squares test for the Korean cattle population. The relationships between phenotypes (C18:1, MUFAs and MS) and individual SNPs for the 513 samples were analyzed using the following mixed analysis of covariance (ANCOVA) model based on SPSS v19.0 (SPSS Inc., 
Chicago, IL, USA).

$$
y_{i j k l}=\mu+S_{i}+P_{j}+G_{k}+\beta_{A g e}+e_{i j k}
$$

where $y_{i j k l}$ is the phenotype, $\mu$ is the overall mean, $S_{i}$ is the random effect of sire $i$ with an assumption of independent and identical normal distribution, $P_{j}$ is the fixed effect of calving place $\mathrm{j}$ (14 classes), $G_{k}$ is the fixed effect of genotype $k, \beta$ is the regression coefficient, age is a covariate for age in days at slaughter, $e_{i j k l}$ is the random residual assumed to have independent and identical normal distribution.

\section{MDR analysis}

The MDR method, a non-parametric and model-free technique, was initially implemented in case-control studies (Hahn et al., 2003). For its application to continuous data, the classification and regression tree (CART) algorithm has been developed and combined with the MDR method (Paolo, 2003). The expanded MDR method involves classification into two groups using a regression tree, i.e., high and low groups for phenotypes, and the group's impurity can be defined as:

$$
I(g)=\frac{\sum_{j=1}^{N_{g}}\left(y_{g j}-\overline{y_{g}}\right)^{2}}{N_{g}}
$$

Where $\overline{y_{g}}$ is the mean for the node (group) and $y_{g j}$ is the observation of the $\mathrm{j}^{\text {th }}$ individual in a total of $N_{g}$ individuals in the group $(\mathrm{g}=$ high or low). Each individual is assigned to a cell (e.g., if there are two SNPs with three genotypes per SNP, then there are 9 possible cells), and then each cell can be defined as a high or low group. The expected numbers of high and low groups are:

$$
N_{\text {high }}=\sum_{i=1}^{n} I_{\text {high }}(i) \cdot N_{i}, \text { and } N_{\text {low }}=\sum_{i=1}^{n} I_{\text {low }}(i) \cdot N_{i}
$$

Respectively, where $n$ is the number of total cells and $I_{g}(i)$ is an indicator function in which

$$
\begin{aligned}
I_{\text {high }}(i) & = \begin{cases}1 & i(\text { cell }) \in \text { high group }, \text { and } \\
0 & \text { o.w }\end{cases} \\
I_{\text {low }}(i) & = \begin{cases}1 & i(\text { cell }) \in \text { low group } . \\
0 & \text { o.w }\end{cases}
\end{aligned}
$$

Then the average squared error (ASE) is:

$$
A S E=S_{\text {high }} / N_{\text {high }}+S_{\text {low }} / N_{\text {low }}
$$

where $S_{h i g h}=\sum_{i=1}^{n} I_{h i g h}(i) \frac{\sum_{j=1}^{N_{i}}\left(y_{i j}-\bar{y}_{i}\right)^{2}}{N_{i}}$ is the sum of squared errors for the high group, $S_{\text {low }}=\sum_{i=1}^{n} I_{\text {low }}(i) \frac{\sum_{j=1}^{N_{i}}\left(y_{i j}-\bar{y}_{i}\right)^{2}}{N_{i}}$ is that for low group, and $y_{i j}$ is the phenotype of the $j^{\text {th }}$ individual in the $i^{\text {th }}$ cell.

In this study, the procedures for the expanded MDR method were as follows:

Step 1: Data were randomly divided into 10 equal parts (one testing set and nine training sets for cross-validation purpose).

Step 2: A set of $n$ SNPs was selected from the pool of all SNPs.

Step 3: Based on the observed level of each $n$, steers were partitioned into classes, referred to as cells. If $n=2$, then a set of two SNPs was selected, and, because a SNP had three genotypes, there were $3^{2}=9$ possible cells. Phenotypic means were calculated within each cell.

Step 4: The impurity function in the CART algorithm used the variance impurity such that the group with the higher average value was labeled as high and the rest was labeled as low.

Step 5: The expanded MDR model with the smallest ASE was chosen among all two-factor combinations.

Step 6: For the evaluation of the predictive ability of the model, the predicted ASE (P_ASE) was estimated using a 10 -fold cross-validation method. These six steps were repeated for each possible combination of given $n$. The model with the minimum predicted ASE was selected as the best model, but for the selected model, statistical significance was not determined by the predicted ASE. Therefore, permutation tests were performed to determine the empirical significance thresholds by applying the same MDR method (Good, 1994). Before the MDR implementation, phenotypes were adjusted for contemporary and, sire/steer's age effects by using residuals obtained after fitting the general linear model without SNP effects.

\section{RESULTS AND DISCUSSION}

The SCD is an endoplasmic reticulum (ER) enzyme that catalyzes the biosynthesis of MUFAs from saturated fatty acids that are either synthesized de novo or derived from the diet (Smith et al., 2006). Variations in SCD enzyme activity in mammals are likely to affect a variety of key physiological variables, including cellular differentiation, insulin sensitivity, metabolic rates, adiposity, atherosclerosis, cancer, and obesity (Paton and Ntambi, 2009). Two types of SCD gene isoforms have been characterized in cattle, 
namely SCD1, expressed mainly in adipose tissue, and SCD5, expressed mainly in the brain (Lengi and Corl, 2007). The expression of SCD1 in bovine adipose tissue is regulated by numerous factors. The SCD1 mRNA level in muscle tissue has been reported to increase after weaning until 12 mon of age (Lee et al., 2005) but also during the late fattening stages (Kwon et al., 2009), and its development was dependent on the breed and diet (Chung et al., 2007). Breed differences in the SCD1 mRNA level have been found Japanese Black and Holstein steers (Taniguchi et al., 2004). Based on these reports, we collected 15 SNPs suggested by dbSNP of NCBI to identify those SNPs related to fatty acids in the SCD1 gene (Oh et al., 2011). These SNPs were located at 3 SNPs in the intron region, 3 SNPs in the exon 5 region and 9 SNPs in the 3'UTR region. By SBE method for verification of 15 SNPs in 45 extreme steers for the high and low MUFAs group of Korean native cattle, 15 polymorphic SNPs were identified (Table 1). And they were excluded in the following genetic association analysis. The other loci had their minor allele frequency ranging from 0.233 to 0.500 , and their genotypes did not deviate from the Hardy-Weinberg equilibrium ( $p>0.05$, Table 1)

Table 2 shows the efficiency of discrimination for the 15 polymorphic SNPs in the high and low MUFAs groups ( $\mathrm{n}=$ 45). For the classification of 45 extreme animals into these two groups, the discriminant coefficients were calculated for the 15 polymorphic SNPs by using information on SNP genotypes the high- and low-MUFAs groups. The discriminant coefficients for 7 of these 15 SNPs (g.6850+77 A $>$ G, g.8646+128 A>G, g.10153 A>G, g.10213 T>C, g.10329 C>T, g. $14047 \mathrm{C}>\mathrm{T}$ and g.14578 $\mathrm{A}>\mathrm{G}$ ) were -1.786 , $-0.500,-1.267,-0.424,-0.954,-0.966$, and -0.944 , respectively. These 7 SNPs showed significant relationships with MUFAs $(p<0.05, F>2.5)$. This is equivalent to a discriminative error of $2.1 \%$ and a high correlation ratio of 0.91 . These results indicate that the discriminant function successfully separated extreme cattle (Tsuji et al., 2008). Therefore, these 7 SNPs were selected for large scale genotyping in the Korean native cattle $(n=513)$.

Table 1. Genotype and frequency of 15 polymorphic SNPs of the SCD gene in Korean native cattle

\begin{tabular}{|c|c|c|c|c|c|c|c|c|}
\hline \multirow{3}{*}{$\begin{array}{l}\text { SNP } \\
\text { g.6850+77 A>G }\end{array}$} & \multirow{3}{*}{$\begin{array}{c}\text { Region } \\
\text { Intron }\end{array}$} & \multicolumn{4}{|c|}{ Genotype (No. of animals) } & \multirow{3}{*}{$\begin{array}{c}\mathrm{H}^{1} \\
0.358\end{array}$} & \multirow{3}{*}{$\begin{array}{r}\text { MAF }^{2} \\
0.244\end{array}$} & \multirow{3}{*}{$\begin{array}{r}\text { HWE }^{3} \\
0.708\end{array}$} \\
\hline & & \multicolumn{4}{|c|}{ Frequency } & & & \\
\hline & & $\mathrm{AA}(2)$ & GA (17) & GG (26) & $\mathrm{N}^{4}(45)$ & & & \\
\hline & & 0.044 & 0.378 & 0.578 & 1 & & & \\
\hline \multirow[t]{2}{*}{ g. $8243-72 \mathrm{~A}>\mathrm{G}$} & & $\mathrm{AA}(3)$ & GA (22) & GG (20) & $\mathrm{N}(45)$ & 0.429 & 0.233 & 0.345 \\
\hline & & 0.067 & 0.489 & 0.444 & 1 & & & \\
\hline \multirow[t]{2}{*}{ g. $8646+128 \mathrm{~A}>\mathrm{G}$} & & $\mathrm{AA}(9)$ & $\mathrm{GA}(21)$ & GG (15) & $\mathrm{N}(45)$ & 0.491 & 0.311 & 0.738 \\
\hline & & 0.200 & 0.467 & 0.333 & 1 & & & \\
\hline \multirow[t]{2}{*}{ g. $10153 \mathrm{~A}>\mathrm{G}$} & Exon 5 & AA (10) & GA (19) & GG (16) & $\mathrm{N}(45)$ & 0.491 & 0.433 & 0.345 \\
\hline & & 0.222 & 0.422 & 0.356 & 1 & & & \\
\hline \multirow[t]{2}{*}{ g. $10213 \mathrm{~T}>\mathrm{C}$} & & CC (13) & CT (22) & TT (10) & $\mathrm{N}(45)$ & 0.498 & 0.448 & 0.905 \\
\hline & & 0.289 & 0.489 & 0.222 & 1 & & & \\
\hline \multirow[t]{2}{*}{ g. $10329 \mathrm{C}>\mathrm{T}$} & & $\mathrm{CC}(10)$ & CT (20) & TT (15) & $\mathrm{N}(45)$ & 0.494 & 0.467 & 0.502 \\
\hline & & 0.222 & 0.444 & 0.333 & 1 & & & \\
\hline \multirow[t]{2}{*}{ g. $13565 \mathrm{G}>\mathrm{T}$} & 3'UTR & GG (8) & GT (21) & TT (16) & $\mathrm{N}(45)$ & 0.484 & 0.444 & 0.808 \\
\hline & & 0.178 & 0.467 & 0.356 & 1 & & & \\
\hline \multirow[t]{2}{*}{ g. $13757 \mathrm{C}>\mathrm{A}$} & & $\mathrm{AA}(12)$ & GA (22) & GG (11) & $\mathrm{N}(45)$ & 0.499 & 0.489 & 0.884 \\
\hline & & 0.267 & 0.489 & 0.244 & 1 & & & \\
\hline \multirow[t]{2}{*}{ g. $14047 \mathrm{C}>\mathrm{T}$} & & $\mathrm{CC}(10)$ & CT (23) & TT (12) & $\mathrm{N}(45)$ & 0.499 & 0.478 & 0.871 \\
\hline & & 0.222 & 0.511 & 0.267 & 1 & & & \\
\hline \multirow[t]{2}{*}{ g. $14578 \mathrm{~A}>\mathrm{G}$} & & AA (11) & $\mathrm{GA}(20)$ & GG (14) & $\mathrm{N}(45)$ & 0.498 & 0.467 & 0.472 \\
\hline & & 0.244 & 0.444 & 0.311 & 1 & & & \\
\hline \multirow[t]{2}{*}{ g. $15001 \mathrm{~A}>\mathrm{G}$} & & AA (10) & $\mathrm{GA}(20)$ & GG (15) & $\mathrm{N}(45)$ & 0.494 & 0.444 & 0.502 \\
\hline & & 0.222 & 0.444 & 0.333 & 1 & & & \\
\hline \multirow[t]{2}{*}{ g.15101 C>T } & & CC (10) & CT (23) & TT (12) & $\mathrm{N}(45)$ & 0.499 & 0.478 & 0.871 \\
\hline & & 0.222 & 0.511 & 0.267 & 1 & & & \\
\hline \multirow[t]{2}{*}{ g. $15202 \mathrm{G}>\mathrm{A}$} & & $\mathrm{AA}(11)$ & GA (23) & GG (11) & $\mathrm{N}(45)$ & 0.500 & 0.500 & 0.881 \\
\hline & & 0.244 & 0.511 & 0.244 & 1 & & & \\
\hline \multirow[t]{2}{*}{ g. $15491 \mathrm{G}>\mathrm{A}$} & & AA (13) & GA (23) & GG (9) & $\mathrm{N}(45)$ & 0.496 & 0.456 & 0.839 \\
\hline & & 0.289 & 0.511 & 0.200 & 1 & & & \\
\hline \multirow[t]{2}{*}{ g.16524 C>T } & & CC (8) & CT (26) & TT (11) & $\mathrm{N}(45)$ & 0.498 & 0.467 & 0.280 \\
\hline & & 0.178 & 0.578 & 0.244 & 1 & & & \\
\hline
\end{tabular}

${ }^{1}$ Heterozygosity. ${ }^{2}$ Minor allele frequency. ${ }^{3}$ Hardy-Weinberg equilibrium. ${ }^{4}$ Total number. 
Table 2. Efficiency of discrimination for 15 ploymorphic SNPs in high and low MUFAs groups of Korean native cattle $(n=45)$

\begin{tabular}{|c|c|c|c|c|c|c|c|c|c|}
\hline \multirow{3}{*}{ SNP } & \multicolumn{3}{|c|}{ High MUFAs group } & \multicolumn{3}{|c|}{ Low MUFAs group } & \multirow{3}{*}{$\begin{array}{l}\text { Discriminant } \\
\text { coefficient }\end{array}$} & \multirow{3}{*}{ F-value } & \multirow{3}{*}{$\mathrm{p}$-value } \\
\hline & \multirow{2}{*}{\multicolumn{3}{|c|}{$\begin{array}{c}\text { observed genotype } \\
\text { No. of animals (Frequency) }\end{array}$}} & \multirow{2}{*}{\multicolumn{3}{|c|}{$\begin{array}{c}\text { observed genotype } \\
\text { No. of animals (Frequency) }\end{array}$}} & & & \\
\hline & & & & & & & & & \\
\hline \multirow[t]{2}{*}{ g.6850+77 A>G } & $\mathrm{AA}$ & GA & GG & AA & GA & GG & -1.786 & 5.041 & 0.011 \\
\hline & $2(1.00)$ & $12(0.71)$ & $8(0.31)$ & $0(0.00)$ & $5(0.29)$ & $18(0.69)$ & & & \\
\hline \multirow[t]{2}{*}{ g. $8243-72$ A>G } & $\mathrm{AA}$ & GA & GG & AA & GA & GG & -0.305 & 0.241 & 0.787 \\
\hline & $2(0.67)$ & $11(0.5)$ & $9(0.45)$ & $1(0.33)$ & $11(0.5)$ & $11(0.55)$ & & & \\
\hline \multirow[t]{2}{*}{ g. $8646+128$ A $>G$} & AA & GA & GG & AA & GA & GG & -0.500 & 3.041 & 0.058 \\
\hline & $4(0.44)$ & $14(0.67)$ & $4(0.27)$ & $5(0.56)$ & $7(0.33)$ & $11(0.73)$ & & & \\
\hline \multirow[t]{2}{*}{ g. $10153 \mathrm{~A}>\mathrm{G}$} & AA & GA & GG & $\mathrm{AA}$ & GA & GG & -1.267 & 5.358 & 0.008 \\
\hline & $7(0.70)$ & $12(0.63)$ & $3(0.19)$ & $3(0.30)$ & $7(0.37)$ & $13(0.81)$ & & & \\
\hline \multirow[t]{2}{*}{ g.10213 T>C } & TT & $\mathrm{CT}$ & $\mathrm{CC}$ & TT & $\mathrm{CT}$ & TT & -0.424 & 3.907 & 0.028 \\
\hline & $4(0.40)$ & $15(0.68)$ & $3(0.23)$ & $6(0.60)$ & $7(0.32)$ & $10(0.77)$ & & & \\
\hline \multirow[t]{2}{*}{ g.10329 C > T } & $\mathrm{CC}$ & $\mathrm{CT}$ & $\mathrm{TT}$ & $\mathrm{CC}$ & $\mathrm{CT}$ & TT & -0.954 & 4.255 & 0.021 \\
\hline & $6(0.60)$ & $13(0.65)$ & $3(0.20)$ & $4(0.40)$ & $7(0.35)$ & $12(0.80)$ & & & \\
\hline \multirow[t]{2}{*}{ g.13565 G>T } & GG & GT & $\mathrm{TT}$ & GG & GT & $\mathrm{TT}$ & 0.185 & 0.248 & 0.781 \\
\hline & $3(0.38)$ & $11(0.52)$ & $8(0.50)$ & $5(0.62)$ & $10(0.48)$ & $8(0.50)$ & & & \\
\hline \multirow[t]{2}{*}{ g. $13757 \mathrm{C}>\mathrm{A}$} & $\mathrm{CC}$ & $\mathrm{CA}$ & AA & $\mathrm{CC}$ & $\mathrm{CA}$ & AA & -0.811 & 1.919 & 0.159 \\
\hline & $8(0.73)$ & $10(0.46)$ & $4(0.33)$ & $3(0.27)$ & $12(0.54)$ & $8(0.67)$ & & & \\
\hline \multirow[t]{2}{*}{ g. $14047 \mathrm{C}>\mathrm{T}$} & $\mathrm{CC}$ & $\mathrm{CT}$ & $\mathrm{TT}$ & $\mathrm{CC}$ & $\mathrm{CT}$ & $\mathrm{TT}$ & -0.966 & 3.739 & 0.032 \\
\hline & $6(0.60)$ & $14(0.61)$ & $2(0.17)$ & $4(0.40)$ & $9(0.39)$ & $10(0.83)$ & & & \\
\hline \multirow[t]{2}{*}{ g. $14578 \mathrm{~A}>\mathrm{G}$} & AA & GA & GG & AA & GA & GG & -0.944 & 3.337 & 0.045 \\
\hline & $7(0.64)$ & $12(0.60)$ & $3(0.21)$ & $4(0.36)$ & $8(0.40)$ & 11(0.79) & & & \\
\hline \multirow[t]{2}{*}{ g.15001 A>G } & AA & GA & GG & AA & GA & GG & -0.069 & 0.021 & 0.979 \\
\hline & $5(0.50)$ & $10(0.50)$ & $7(0.47)$ & $5(0.50)$ & $10(0.50)$ & $8(0.53)$ & & & \\
\hline \multirow[t]{2}{*}{ g.15101 C>T } & $\mathrm{CC}$ & $\mathrm{CT}$ & $\mathrm{TT}$ & $\mathrm{CC}$ & $\mathrm{CT}$ & $\mathrm{TT}$ & 0.179 & 0.199 & 0.821 \\
\hline & $4(0.40)$ & $12(0.52)$ & $6(0.50)$ & $6(0.60)$ & $11(0.48)$ & $6(0.50)$ & & & \\
\hline \multirow[t]{2}{*}{ g. $15202 \mathrm{G}>\mathrm{A}$} & GG & GA & AA & GG & GA & AA & 0.000 & 0.095 & 0.909 \\
\hline & $5(0.46)$ & $12(0.52)$ & $5(0.46)$ & $6(0.54)$ & $11(0.48)$ & $6(0.54)$ & & & \\
\hline \multirow[t]{2}{*}{ g.15491 G>A } & GG & GA & AA & GG & GA & $\mathrm{AA}$ & 0.185 & 0.098 & 0.907 \\
\hline & $4(0.44)$ & $11(0.48)$ & $7(0.54)$ & $5(0.56)$ & $12(0.52)$ & $6(0.46)$ & & & \\
\hline \multirow[t]{2}{*}{ g. $16524 \mathrm{C}>\mathrm{T}$} & $\mathrm{CC}$ & $\mathrm{CT}$ & $\mathrm{TT}$ & $\mathrm{CC}$ & $\mathrm{CT}$ & $\mathrm{TT}$ & -0.302 & 0.343 & 0.712 \\
\hline & $5(0.63)$ & $12(0.46)$ & $5(0.46)$ & $3(0.37)$ & $14(0.54)$ & $6(0.54)$ & & & \\
\hline
\end{tabular}

The MDR method, a novel technique, was applied to examine the interactions between the 7 polymorphic SNP genotypes in complex traits (C18:1, MUFAs and MS). These were applied to the MDR method, and superior twoand three-way SNP combinations were used for each trait. Here $p<0.05$ was used to determine statistical significance for the critical value in the t-test and permutation test. For the investigation of two- and three-way SNP gene interactions, the top 5 combinations were listed for each trait (Tables 3 and 6). The ranking was determined based on the training-balanced accuracy of results for each trait.

Table 3 shows that the g.10213 T>C and g.14047 C>T combination had the highest score for both trainingbalanced accuracy $(60.16 \%)$ and testing-balanced accuracy $(57.42 \%)$ in the two-way interaction model of C18:1. The g.10329 $\mathrm{C}>\mathrm{T}$ and g.14047 $\mathrm{C}>\mathrm{T}$ combination represented the best two-way interaction model of MUFAs. In case of MS, the g.10153 A>G and g.10213 $\mathrm{T}>\mathrm{C}$ combination represented the highest training-balanced accuracy $(56.78 \%)$.

The best interaction models of C18:1, MUFAs and MS were not the same, and therefore 4 superior SNP combinations (g.10213 T>C and g.14047 C>T; g.14047 C> T and g.14578 A>G; g.10329 $\mathrm{C}>\mathrm{T}$ and g.14047 C>T; and g.6850+77 $\mathrm{A}>\mathrm{G}$ and g.14047 $\mathrm{C}>\mathrm{T}$ ) were calculated and compared (Table 4). Then, the g.6850+77 A $>\mathrm{G}$ and g.14047 C> T SNP interaction was selected as the statistically best combination (C18:1, MUFAs and MS permutation t-values were $7.091,7.017$ and 3.293 respectively) of two-way interactions.

The single and combination effects of g.6850+77 A>G and g.14047 $\mathrm{C}>\mathrm{T}$ were examined (Table 5). As shown in the table, the combination effects of g.6850+77 $\mathrm{A}>\mathrm{G}$ and g.14047 C>T on C18:1, MUFAs and MS traits were better than their individual effects. In particular, g.6850+77 A>G and g.14047 $\mathrm{C}>\mathrm{T}$ SNPs were not significant (with 
Table 3. Significant SNP combinations of top 5 two-way gene interactions from 3 traits based on MDR method in Korean native cattle

\begin{tabular}{|c|c|c|c|c|c|c|c|c|c|}
\hline \multirow[b]{2}{*}{ Rank } & \multirow[b]{2}{*}{$\mathrm{SNP}^{4}$} & \multicolumn{2}{|c|}{ C18:1 ${ }^{1}$} & \multirow[b]{2}{*}{ SNP } & \multicolumn{2}{|c|}{ MUFAs $^{2}$} & \multirow[b]{2}{*}{ SNP } & \multicolumn{2}{|c|}{$\mathrm{MS}^{3}$} \\
\hline & & $\begin{array}{l}\text { Training- } \\
\text { balanced } \\
\text { accuracy }\end{array}$ & $\begin{array}{l}\text { Testing- } \\
\text { balanced } \\
\text { accuracy }\end{array}$ & & $\begin{array}{l}\text { Training- } \\
\text { balanced } \\
\text { accuracy }\end{array}$ & $\begin{array}{l}\text { Testing- } \\
\text { balanced } \\
\text { accuracy }\end{array}$ & & $\begin{array}{l}\text { Training- } \\
\text { balanced } \\
\text { accuracy }\end{array}$ & $\begin{array}{l}\text { Testing- } \\
\text { balanced } \\
\text { accuracy }\end{array}$ \\
\hline 1 & $\begin{array}{l}\text { g.10213 T>C, } \\
\text { g.14047 C>T }\end{array}$ & 0.6016 & 0.5742 & $\begin{array}{l}\text { g.10329 C>T, } \\
\text { g. } 14047 \mathrm{C}>\mathrm{T}\end{array}$ & 0.6140 & 0.5585 & $\begin{array}{l}\text { g.10153 A>G, } \\
\text { g.10213 T>C }\end{array}$ & 0.5678 & 0.4839 \\
\hline 2 & $\begin{array}{l}\text { g. } 14047 \mathrm{C}>\mathrm{T}, \\
\text { g.14578 A>G }\end{array}$ & 0.5997 & 0.5625 & $\begin{array}{l}\text { g. } 14047 \mathrm{C}>\mathrm{T}, \\
\text { g. } 14578 \mathrm{~A}>\mathrm{G}\end{array}$ & 0.6131 & 0.5644 & $\begin{array}{l}\text { g. } 6850+77 \mathrm{~A}>\mathrm{G} \\
\text { g. } 10329 \mathrm{C}>\mathrm{T}\end{array}$ & 0.5642 & 0.4664 \\
\hline 3 & $\begin{array}{l}\text { g. } 10329 \mathrm{C}>\mathrm{T}, \\
\text { g. } 14047 \mathrm{C}>\mathrm{T}\end{array}$ & 0.5386 & 0.5640 & $\begin{array}{l}\text { g. } 6850+77 \mathrm{~A}>\mathrm{G}, \\
\text { g. } 14047 \mathrm{C}>\mathrm{T}\end{array}$ & 0.6109 & 0.5387 & $\begin{array}{l}\text { g. } 6850+77 \mathrm{~A}>\mathrm{G}, \\
\text { g. } 14578 \mathrm{~A}>\mathrm{G}\end{array}$ & 0.5634 & 0.4675 \\
\hline 4 & $\begin{array}{l}\text { g. } 10153 \mathrm{~A}>\mathrm{G}, \\
\text { g. } 14047 \mathrm{C}>\mathrm{T}\end{array}$ & 0.5968 & 0.5683 & $\begin{array}{l}\text { g. } 10213 \mathrm{~T}>\mathrm{C}, \\
\text { g. } 14047 \mathrm{C}>\mathrm{T}\end{array}$ & 0.6056 & 0.5821 & $\begin{array}{l}\text { g. } 6850+77 \mathrm{~A}>\mathrm{G}, \\
\text { g. } 14047 \mathrm{C}>\mathrm{T}\end{array}$ & 0.5608 & 0.4827 \\
\hline 5 & $\begin{array}{l}\text { g. } 6850+77 A>G, \\
\text { g. } 14047 \mathrm{C}>\mathrm{T}\end{array}$ & 0.5961 & 0.5464 & $\begin{array}{l}\text { g. } 8646+128 \mathrm{~A}>\mathrm{G}, \\
\text { g. } 14047 \mathrm{C}>\mathrm{T}\end{array}$ & 0.6013 & 0.5762 & $\begin{array}{l}\text { g. } 8646+128 \mathrm{~A}>\mathrm{G}, \\
\text { g. } 10213 \mathrm{~T}>\mathrm{C}\end{array}$ & 0.5575 & 0.4927 \\
\hline
\end{tabular}

${ }^{1}$ Oleic acid. ${ }^{2}$ Monounsaturated fatty acids. ${ }^{3}$ Marbling score. ${ }^{4}$ SNP combination.

permutation $\mathrm{p}$ values of 0.060 and 0.192 respectively) in CCAA, CCAG, CCGG and CTAG from MS (5.76 \pm 0.13$)$. MS. However, the g.6850+77 A>G and g.14047 C>T Therefore, the CCAA, CCAG and CTAG genotype of the combination was highly significant with p-value 0.001. In g.6850+77 $\mathrm{A}>\mathrm{G}$ and g.14047 $\mathrm{C}>\mathrm{T}$ combination had the terms of superior genotypes CCAA, CCAG, CCGG and greatest interaction effects on all 3 traits. Because all these CTAG were obtained from C18:1 (45.24 \pm 0.18$)$; CCAA, combinations were significant, the best combination was CCAG, CTAA and CTAG from MUFAs $(54.70 \pm 0.23)$ and determined based on the t-value.

Table 4. The selected of 4 combinations based on two-way gene interactions for 3 traits in Korean native cattle

\begin{tabular}{|c|c|c|c|c|c|c|}
\hline $\mathrm{SNP}^{1}$ & Traits $^{2}$ & Genotype & $\mathrm{N}^{3}$ & LSmean \pm SE & t-value & $\begin{array}{c}\text { Permutation } \\
\mathrm{p}^{4}\end{array}$ \\
\hline \multirow[t]{6}{*}{$\overline{\text { g. } 10213 \mathrm{~T}>\mathrm{C}, \text { g. } 14047 \mathrm{C}>\mathrm{T}}$} & C18:1 & ССТT, ССТC, СТTC, СТCC & 315 & $44.92 \pm 0.14$ & $6.921 * * *$ & 0.000 \\
\hline & & Others & 198 & $43.32 \pm 0.18$ & & \\
\hline & MUFA & ССТТ, ССТС, СТТС, СТСС & 315 & $54.17 \pm 0.16$ & $6.691 * * *$ & 0.000 \\
\hline & & Others & 198 & $52.44 \pm 0.20$ & & \\
\hline & MS & $\begin{array}{l}\text { CCTT, СCTC, СТTT, СТTC, СТCC, } \\
\text { TTTT, TTTC }\end{array}$ & 397 & $5.56 \pm 0.10$ & $2.879 * *$ & 0.005 \\
\hline & & Others & 116 & $4.97 \pm 0.17$ & & \\
\hline \multirow[t]{6}{*}{ g.14047 C>T, g. $14578 \mathrm{~A}>\mathrm{G}$} & $\mathrm{C} 18: 1$ & AACC, AGCC, AGCT & 294 & $44.97 \pm 0.15$ & $6.941 * * *$ & 0.000 \\
\hline & & Others & 219 & $43.40 \pm 0.17$ & & \\
\hline & MUFA & AACC, AACT, AGCC, AGCT & 300 & $54.24 \pm 0.16$ & $6.952 * * *$ & 0.000 \\
\hline & & Others & 213 & $52.47 \pm 0.19$ & & \\
\hline & MS & AACC, AGCC, AGCT, AGTT, GGCC & 326 & $5.59 \pm 0.11$ & $2.560 *$ & 0.014 \\
\hline & & Others & 187 & $5.14 \pm 0.14$ & & \\
\hline \multirow[t]{6}{*}{ g.10329 C>T, g. $14047 \mathrm{C}>\mathrm{T}$} & $\mathrm{C} 18: 1$ & СССС, СССТ, СТСТ, СТТТ & 318 & $44.91 \pm 0.14$ & $6.888 * * *$ & 0.000 \\
\hline & & Others & 195 & $43.31 \pm 0.18$ & & \\
\hline & MUFA & СССС, СССТ, СТСТ, СТТТ & 318 & $54.18 \pm 0.16$ & $6.828 * * *$ & 0.000 \\
\hline & & Others & 195 & $52.41 \pm 0.20$ & & \\
\hline & MS & $\begin{array}{l}\text { СCСC, СССТ, СТСТ, СТTТ, ТТСC, } \\
\text { TTCT }\end{array}$ & 373 & $5.60 \pm 0.10$ & $3.290 * *$ & 0.002 \\
\hline & & Others & 140 & $4.97 \pm 0.16$ & & \\
\hline \multirow[t]{6}{*}{ g. $6850+77 \mathrm{~A}>\mathrm{G}$, g. $14047 \mathrm{C}>\mathrm{T}$} & $\mathrm{C} 18: 1$ & CCAA, CCAG, CCGG, CTAG & 214 & $45.24 \pm 0.18$ & $7.091 * * *$ & 0.000 \\
\hline & & Others & 299 & $43.63 \pm 0.14$ & & \\
\hline & MUFA & CCAA, CCAG, CTAA, CTAG & 181 & $54.70 \pm 0.23$ & $7.017 * * *$ & 0.000 \\
\hline & & Others & 332 & $52.86 \pm 0.15$ & & \\
\hline & MS & $\begin{array}{l}\text { CCAA, CCAG, CCGG, CTAG, TTAA, } \\
\text { TTAG }\end{array}$ & 214 & $5.76 \pm 0.13$ & $3.293 * *$ & 0.001 \\
\hline & & Others & 299 & $5.19 \pm 0.11$ & & \\
\hline
\end{tabular}

\footnotetext{
${ }^{1}$ SNP combination. ${ }^{2} \mathrm{C} 18: 1=$ Oleic acid, MUFA $=$ Monounsaturated fatty acids, MS $=$ Marbling score.
}

${ }^{3}$ Number of animals. ${ }^{4}$ Permutation $\mathrm{p}$ value. ${ }^{*} \mathrm{p}<0.05 .{ }^{*} \mathrm{p}<0.01 . * * * \mathrm{p}<0.001$. 
Table 5. Single and combinations effect of 2 SNPs for 3 traits in Korean native cattle

\begin{tabular}{|c|c|c|c|c|c|c|}
\hline Traits $^{1}$ & SNP & Genotype & $\mathrm{N}^{2}$ & LSmean \pm SE & t-value & $\mathrm{p}^{3}$ \\
\hline \multirow[t]{6}{*}{$\overline{\mathrm{C} 18: 1}$} & g. $6850+77 \mathrm{~A}>\mathrm{G}$ & $\mathrm{AA}, \mathrm{AG}$ & 220 & $45.03 \pm 0.20$ & $5.380 * * *$ & 0.000 \\
\hline & & GG & 293 & $43.75 \pm 0.14$ & & \\
\hline & g. $14047 \mathrm{C}>\mathrm{T}$ & $\mathrm{CC}, \mathrm{CT}$ & 332 & $44.86 \pm 0.14$ & $6.688 * * *$ & 0.000 \\
\hline & & TT & 181 & $43.28 \pm 0.19$ & & \\
\hline & Combination & CCAA, CCAG, CCGG, CTAG & 214 & $45.24 \pm 0.18$ & $7.091 * * *$ & 0.000 \\
\hline & & Others & 299 & $43.63 \pm 0.14$ & & \\
\hline \multirow[t]{6}{*}{ MUFAs } & g. $6850+77 \mathrm{~A}>\mathrm{G}$ & $\mathrm{AA}, \mathrm{AG}$ & 220 & $54.28 \pm 0.22$ & $5.136 * * *$ & 0.000 \\
\hline & & GG & 293 & $52.92 \pm 0.15$ & & \\
\hline & g. $14047 \mathrm{C}>\mathrm{T}$ & $\mathrm{CC}, \mathrm{CT}$ & 332 & $54.09 \pm 0.16$ & $6.268 * * *$ & 0.000 \\
\hline & & $\mathrm{TT}$ & 181 & $52.43 \pm 0.21$ & & \\
\hline & Combination & CCAA, CCAG, CTAA, CTAG & 181 & $54.70 \pm 0.23$ & $7.017 * * *$ & 0.000 \\
\hline & & Others & 332 & $52.86 \pm 0.15$ & & \\
\hline \multirow[t]{6}{*}{ MS } & g. $6850+77 \mathrm{~A}>\mathrm{G}$ & $\mathrm{AA}, \mathrm{AG}$ & 220 & $5.29 \pm 0.13$ & 1.802 & 0.060 \\
\hline & & GG & 293 & $5.60 \pm 0.11$ & & \\
\hline & g. $14047 \mathrm{C}>\mathrm{T}$ & $\mathrm{CC}, \mathrm{CT}$ & 332 & $5.24 \pm 0.11$ & 1.348 & 0.192 \\
\hline & & $\mathrm{TT}$ & 181 & $5.51 \pm 0.15$ & & \\
\hline & Combination & $\begin{array}{l}\text { CCAA, CCAG, CCGG, CTAG, } \\
\text { TTAA, TTAG }\end{array}$ & 214 & $5.76 \pm 0.13$ & $3.293 * *$ & 0.001 \\
\hline & & Others & 299 & $5.19 \pm 0.11$ & & \\
\hline
\end{tabular}

${ }^{1}$ C18:1 = Oleic acid, MUFA = Monounsaturated fatty acids, MS = Marbling score.

${ }^{2}$ Number of animals. ${ }^{3}$ Permutation $\mathrm{p}$ value. ${ }^{*} \mathrm{p}<0.05$. ** $\mathrm{p}<0.01$. *** $\mathrm{p}<0.001$.

For the three-way interaction model, the g.6850+77 A $>$ G, g.10213 T>C and g.14047 C>T combination showed the highest training-balanced accuracy $(63.76 \%, 64.70 \%$ and $61.85 \%$ respectively) (Table 6). Noteworthy is that g.6850+77 $\mathrm{A}>\mathrm{G}$ and g.14047 $\mathrm{C}>\mathrm{T}$ were also observed in the two-way interaction model. As shown in Table 7, the individual and interaction effects of g.6850+77 $\mathrm{A}>\mathrm{G}$, g.10213 T>C and g.14047 $\mathrm{C}>\mathrm{T}$ were examined and compared for C18:1, MUFAs and MS. The superior genotype groups were $45.45 \pm 0.13$ for $\mathrm{C} 18: 1,54.73 \pm 0.22$ for MUFAs and $5.95 \pm 0.12$ for MS and significant (all permutation p-values were 0.000) (Table 7). By contrast, the average for the ht $1 *$ ht 2 haplotype group $(\mathrm{g} .10153 \mathrm{~A}>\mathrm{G}$, g.10213 T>C and g.10329 C>T) was 44.92 for $\mathrm{C} 18: 1$, as described in Oh et al. (2011); However, in this study, the average for genotype of g.6850+77 A>G (AA, AG),

Table 6. Significant SNP combinations of top 5 three-way gene interactions from 3 traits based on the MDR method in Korean native cattle

\begin{tabular}{|c|c|c|c|c|c|c|c|c|c|}
\hline \multirow[b]{2}{*}{ Rank } & \multirow[b]{2}{*}{$\mathrm{SNP}^{4}$} & \multicolumn{2}{|c|}{ C18:1 ${ }^{1}$} & \multirow[b]{2}{*}{ SNP } & \multicolumn{2}{|c|}{ MUFAs $^{2}$} & \multirow[b]{2}{*}{ SNP } & \multicolumn{2}{|c|}{$\mathrm{MS}^{3}$} \\
\hline & & $\begin{array}{l}\text { Training- } \\
\text { balanced } \\
\text { accuracy }\end{array}$ & $\begin{array}{l}\text { Testing- } \\
\text { balanced } \\
\text { accuracy }\end{array}$ & & $\begin{array}{l}\text { Training- } \\
\text { balanced } \\
\text { accuracy }\end{array}$ & $\begin{array}{l}\text { Testing- } \\
\text { balanced } \\
\text { accuracy }\end{array}$ & & $\begin{array}{l}\text { Training- } \\
\text { balanced } \\
\text { accuracy }\end{array}$ & $\begin{array}{l}\text { Testing- } \\
\text { balanced } \\
\text { accuracy }\end{array}$ \\
\hline 1 & $\begin{array}{l}\text { g. } 6850+77 \mathrm{~A}>\mathrm{G}, \\
\text { g. } 10213 \mathrm{~T}>\mathrm{C}, \\
\text { g. } 14047 \mathrm{C}>\mathrm{T}\end{array}$ & 0.6376 & 0.5851 & $\begin{array}{l}\text { g. } 6850+77 \mathrm{~A}>\mathrm{G}, \\
\text { g. } 10213 \mathrm{~T}>\mathrm{C}, \\
\text { g. } 14047 \mathrm{C}>\mathrm{T}\end{array}$ & 0.6470 & 0.5789 & $\begin{array}{l}\text { g. } 6850+77 \mathrm{~A}>\mathrm{G}, \\
\text { g. } 10213 \mathrm{~T}>\mathrm{C}, \\
\text { g. } 14047 \mathrm{C}>\mathrm{T}\end{array}$ & 0.6185 & 0.5900 \\
\hline 2 & $\begin{array}{l}\text { g. } 8646+128 \mathrm{~A}>\mathrm{G}, \\
\text { g. } 10153 \mathrm{~A}>\mathrm{G}, \\
\text { g. } 14047 \mathrm{C}>\mathrm{T}\end{array}$ & 0.6351 & 0.5860 & $\begin{array}{l}\text { g. } 8646+128 \mathrm{~A}>\mathrm{G}, \\
\text { g. } 10153 \mathrm{~A}>\mathrm{G}, \\
\text { g. } 14047 \mathrm{C}>\mathrm{T}\end{array}$ & 0.6432 & 0.5758 & $\begin{array}{l}\text { g. } 6850+77 \mathrm{~A}>\mathrm{G}, \\
\text { g. } 8646+128 \mathrm{~A}>\mathrm{G}, \\
\text { g. } 10213 \mathrm{~T}>\mathrm{C}\end{array}$ & 0.6092 & 0.5722 \\
\hline 3 & $\begin{array}{l}\text { g. } 6850+77 \mathrm{~A}>\mathrm{G}, \\
\text { g. } 10153 \mathrm{~A}>\mathrm{G}, \\
\text { g. } 14047 \mathrm{C}>\mathrm{T}\end{array}$ & 0.6314 & 0.5927 & $\begin{array}{l}\text { g. } 6850+77 \mathrm{~A}>\mathrm{G}, \\
\text { g. } 10329 \mathrm{C}>\mathrm{T}, \\
\text { g. } 14047 \mathrm{C}>\mathrm{T}\end{array}$ & 0.6401 & 0.5619 & $\begin{array}{l}\text { g. } 6850+77 \mathrm{~A}>\mathrm{G}, \\
\text { g. } 10213 \mathrm{~T}>\mathrm{C}, \\
\text { g. } 13757 \mathrm{C}>\mathrm{A}\end{array}$ & 0.6072 & 0.5608 \\
\hline 4 & $\begin{array}{l}\text { g. } 6850+77 \mathrm{~A}>\mathrm{G}, \\
\text { g. } 10329 \mathrm{C}>\mathrm{T}, \\
\text { g. } 14047 \mathrm{C}>\mathrm{T}\end{array}$ & 0.6287 & 0.5923 & $\begin{array}{l}\text { g. } 8646+128 \mathrm{~A}>\mathrm{G}, \\
\text { g. } 10329 \mathrm{C}>\mathrm{T}, \\
\text { g. } 14047 \mathrm{C}>\mathrm{T}\end{array}$ & 0.6339 & 0.6117 & $\begin{array}{l}\text { g. } 6850+77 \mathrm{~A}>\mathrm{G}, \\
\text { g. } 10213 \mathrm{~T}>\mathrm{C}, \\
\text { g. } 14578 \mathrm{~A}>\mathrm{G}\end{array}$ & 0.6057 & 0.5737 \\
\hline 5 & $\begin{array}{l}\text { g. } 6850+77 \mathrm{~A}>\mathrm{G}, \\
\text { g. } 14047 \mathrm{C}>\mathrm{T}, \\
\text { g. } 14578 \mathrm{~A}>\mathrm{G}\end{array}$ & 0.6233 & 0.5608 & $\begin{array}{l}\text { g. } 13757 \mathrm{C}>\mathrm{A} \text {, } \\
\text { g. } 14047 \mathrm{C}>\mathrm{T}, \\
\text { g. } 14578 \mathrm{~A}>\mathrm{G}\end{array}$ & 0.6310 & 0.6263 & $\begin{array}{l}\text { g. } 6850+77 \mathrm{~A}>\mathrm{G}, \\
\text { g. } 10153 \mathrm{~A}>\mathrm{G}, \\
\text { g. } 10329 \mathrm{C}>\mathrm{T}\end{array}$ & 0.5979 & 0.5586 \\
\hline
\end{tabular}

${ }^{1}$ Oleic acid. ${ }^{2}$ Monounsaturated fatty acids. ${ }^{3}$ Marbling score. ${ }^{4}$ SNP combination. 
Table 7. Single and combinations effect of 3 SNPs for 3 traits in Korean native cattle

\begin{tabular}{|c|c|c|c|c|c|c|}
\hline Traits $^{1}$ & SNP & Genotype & $\mathrm{N}^{2}$ & LSmean \pm SE & t-value & $\mathrm{p}^{3}$ \\
\hline \multirow[t]{10}{*}{$\mathrm{C} 18: 1$} & \multirow[t]{2}{*}{ g. $6850+77 \mathrm{~A}>\mathrm{G}$} & $\mathrm{AA}, \mathrm{AG}$ & 220 & $45.03 \pm 0.20$ & $5.380 * * *$ & 0.000 \\
\hline & & GG & 293 & $43.75 \pm 0.14$ & & \\
\hline & \multirow[t]{2}{*}{ g.10213 T>C } & $\mathrm{TT}$ & 112 & $44.91 \pm 0.27$ & $2.743 * *$ & 0.013 \\
\hline & & $\mathrm{TC}, \mathrm{CC}$ & 401 & $44.13 \pm 0.13$ & & \\
\hline & \multirow[t]{2}{*}{ g. $14047 \mathrm{C}>\mathrm{T}$} & $\mathrm{CC}, \mathrm{CT}$ & 332 & $44.86 \pm 0.14$ & $6.688 * * *$ & 0.000 \\
\hline & & $\mathrm{TT}$ & 181 & $43.28 \pm 0.19$ & & \\
\hline & \multirow[t]{4}{*}{ Combination } & AATTCC, AGTTCC, AATCCC, & 189 & $45.45 \pm 0.13$ & $7.484 * * *$ & 0.000 \\
\hline & & AGTCCC, GGTCCC, AGTCCT, & & & & \\
\hline & & GGCCCT, AGCCTT & & & & \\
\hline & & Others & 324 & $43.63 \pm 0.20$ & & \\
\hline \multirow[t]{11}{*}{ MUFAs } & \multirow[t]{2}{*}{ g. $6850+77 \mathrm{~A}>\mathrm{G}$} & $\mathrm{AA}, \mathrm{AG}$ & 220 & $54.28 \pm 0.22$ & $5.136 * * *$ & 0.000 \\
\hline & & GG & 293 & $52.92 \pm 0.15$ & & \\
\hline & \multirow[t]{2}{*}{ g. $10213 \mathrm{~T}>\mathrm{C}$} & TT, TC & 393 & $53.78 \pm 0.15$ & $3.796 * * *$ & 0.003 \\
\hline & & $\mathrm{CC}$ & 120 & $52.62 \pm 0.27$ & & \\
\hline & \multirow[t]{2}{*}{ g. $14047 \mathrm{C}>\mathrm{T}$} & $\mathrm{CC}, \mathrm{CT}$ & 332 & $54.09 \pm 0.16$ & $6.268 * * *$ & 0.000 \\
\hline & & $\mathrm{TT}$ & 181 & $52.43 \pm 0.21$ & & \\
\hline & \multirow[t]{5}{*}{ Combination } & AATTCC, AGTTCC, AATCCC, & 204 & $54.73 \pm 0.22$ & $7.768 * * *$ & 0.000 \\
\hline & & AGTCCC, GGTCCC, GGTTCT, & & & & \\
\hline & & AATCCT, AGTCCT, GGCCCT, & & & & \\
\hline & & AGCCTT & & & & \\
\hline & & Others & 309 & $52.70 \pm 0.15$ & & \\
\hline \multirow[t]{12}{*}{ MS } & \multirow[t]{2}{*}{ g. $6850+77 \mathrm{~A}>\mathrm{G}$} & $\mathrm{AA}, \mathrm{AG}$ & 220 & $5.60 \pm 0.13$ & 1.802 & 0.060 \\
\hline & & GG & 293 & $5.29 \pm 0.11$ & & \\
\hline & \multirow[t]{2}{*}{ g. $10213 \mathrm{~T}>\mathrm{C}$} & TT, TC & 393 & $5.56 \pm 0.10$ & $2.828 * *$ & 0.006 \\
\hline & & $\mathrm{CC}$ & 120 & $4.99 \pm 0.17$ & & \\
\hline & \multirow[t]{2}{*}{ g. $14047 \mathrm{C}>\mathrm{T}$} & $\mathrm{CC}, \mathrm{CT}$ & 332 & $5.51 \pm 0.11$ & 1.348 & 0.192 \\
\hline & & $\mathrm{TT}$ & 181 & $5.27 \pm 0.15$ & & \\
\hline & \multirow[t]{6}{*}{ Combination } & AATTCC, AGTTCC, GGTCCC, & 237 & $5.95 \pm 0.12$ & $5.884 * * *$ & 0.000 \\
\hline & & AATTCT, GGTTCT, AGTCCT, & & & & \\
\hline & & AACCCT, AGCCCT, GGCCCT, & & & & \\
\hline & & AATTTT, GGTTTT, AATCTT, & & & & \\
\hline & & GGTCTT, AACCTT, AGCCTT & & & & \\
\hline & & Others & 276 & $4.97 \pm 0.11$ & & \\
\hline
\end{tabular}

${ }^{1}$ C18:1 = Oleic acid, MUFA = Monounsaturated fatty acids, MS = Marbling score.

${ }^{2}$ Number of animals. ${ }^{3}$ Permutation $p$ value. $* \mathrm{p}<0.05$. ** $\mathrm{p}<0.01$. *** $\mathrm{p}<0.001$.

g.10213 T>C (TT, TC) and g.14047 C>T (CC, CT) SNP combinations was 45.45 , better than 0.53 for the ht $1 *$ ht 2 haplotype group. The combinations effect of SNPs was greater than the single effect for C18:1, MUFAs and MS (Table 7). As in the case of the two-way interaction effect, the individual effect of g.6850+77 A>G and g.14047 C>T on the MS were not significant. In addition, g.6850+77 $\mathrm{A}>\mathrm{G}$, g.10213 T>C and g.14047 C>T had a significant three-way interaction effect, and AATTCC, AGTTCC, GGTCCC, AGTCCT, GGCCCT and AGCCTT belonged to the superior group for all 3 traits.

These results indicate that g.6850+77 $\mathrm{A}>\mathrm{G}(\mathrm{AA}, \mathrm{AG})$, g.10213 T>C (TT, TC) and g.14047 C>T (CC, CT) provided the best SNP combination for $\mathrm{C} 18: 1$, MUFAs and
MS in Korea native cattle. The MDR method is a fast and reliable technique for multiple SNP analyses of potential applications in marker-assisted selection. In addition, this technique, a non-parametric statistical method for detecting gene interactions, is useful for small samples and performs an exhaustive search of all n-locus models, collapsing multi-locus genotypes into high- and low-risk classes (Ritchie et al., 2001). This suggests that, after further development, the MDR method may be used for the genetic assessment of quantitative traits. Finally, these genotypes of individual SNPs and their combinations may be important genetic markers for improving beef quality, which is one of the most important goals in the Korean cattle industry. 


\section{ACKNOWLEDGEMENTS}

Jea-Young Lee's work was supported by the Yeungnam University Research Grant 2012.

\section{REFERENCES}

Alexander, L. J., M. D. MacNeil, T. W. Geary, W. M. Snelling, D. C. Rule, and J. A. Scanga. 2007. Quantitative trait loci with additive effects on palatability and fatty acid composition of meat in a Wagyu-Limousin F2 population. Anim. Genet. 38: 506-513.

Barendse, W., A. Reverter, R. J. Bunch, B. E. Harrison, W. Barris, and M. B. Thomas. 2007. A validated whole-genome association study of efficient food conversion in cattle. Genetics 176:1893-1905.

Barton, L., T. Kott, D. Bures, D. Rehak, R. Zahradkova, and B. Kottova. 2010. The polymorphism of stearoyl-CoA desaturase $(S C D 1)$ and sterol regulatory element binding proyein-1 (SREBP-1) genes and their association with the fatty acid profile of muscle and subcutaneous fat in Fleckvieh bulls. Meat Sci. 85(1):15-20.

Bastione, L., M. Reilly, D. J. Rader, and A. S. Foulkes. 2004. MDR and PRP: A comparison of methods for high-order genotype-phenotype associations. Hum. Hered. 58:82-92.

Chung, K. Y., D. K. Lunt, H. Kawachi, H. Yano, and S. B. Smith. 2007. Lipogenesis and stearoyl-CoA desaturase gene expression and enzyme activity in adipose tissue of short- and long-fed Angus and Wagyu steers fed corn- or hay-based diets. J. Anim. Sci. 85:380-387.

Chung, Y. J., S. Y. Lee, and T. S. Park. 2006. Multifactor dimensionality reduction in the presence of missing observations. In: Proceedings of the 2006 Spring Korean Statistical Society Conference, Pusan National University, Pusan. pp. 31-36.

Erkkilä, A., V. D. F. de Mello, U. Riserius, and D. E. Laaksonen. 2008. Dietary fatty acid and cardiovascular disease: An epidemiological approach. Prog. Lipid Res. 47:172-187.

Folch, J., M. Lee, and G. H. Sloane Stanley. 1957. A simple method for the isolation and purification of total lipids from animal tissue. J. Biol. Chem. 226:497-509.

Good, P. 1994. Permutation test, a practical guide to resampling for testing hypotheses. Springer, New York.

Hahn, L. W., M. D. Ritchie, and J. H. Moore. 2003. Multifactor dimensionality reduction software for detecting gene-gene and gene-environment interactions. Bioinformatics 19:376-382.

Inoue, K., N. Shoji, and M. Kobayashi. 2008. Genetic relations among fat melting point, fatty acid composition and carcass traits in Japanese Black cattle. Anim. Sci. J. 79:1-8.

Kgwatalala, P. M., E. M. Ibeagha-Awemu, J. F. Hayes, and X. Zhao. 2007. Single nucleotide polymorphism in the open reading frame of the stearoyl-CoA desaturase gene and resulting genetic variants in Canadian Holstein and Jersey cows. Mitochondrial DNA. 18:357-362.

Kuchel, H., B. D. Siebert, C. D. K. Bottema, G. C. Webb, A. M. Crawford, S. J. Duncan, P. A. McDonald, J. C. McEwan, and W. S. Pitchford. 2004. Physical mapping of the stearoyl-CoA desaturase $(S C D)$ locus in sheep. Anim. Genet. 35:163.

Kwon, E. G., B. K. Park, H. C. Kim, Y. M. Cho, T. Il Kim, and S. S. Chang. 2009. Effects of fattening period on growth performance, carcass characteristics and lipogenic gene expression in Hanwoo steers. Asian-Aust. J. Anim. Sci. 22: 1654-1660.

Lee, S. H., D. H. Yoon, N. J. Choi, S. H. Hwang, E. Y. Cheong, S. J. Oh, Il. C. Cheong, and C. S. Lee. 2005. Developmental relationship of unsaturated fatty acid composition and stearoylCoA desaturase mRNA level in Hanwoo steers' muscle. AsianAust. J. Anim. Sci. 18:562-566.

Lengi, A. J., and B. A. Corl. 2007. Identification and characterization of a novel bovine stearoyl-CoA desaturase isoform with homology to human SCD5. Lipids 42:499-508.

Mandell, I. B., J. G. Buchanan-Smith, and C. P. Campbell. 1998. Effects of forage vs grain feeding on carcass characteristics, fatty acid composition, and beef quality in Limousin-cross steers when time on feed is controlled. J. Anim. Sci. 76:26192630.

Matsumoto, N., F. Kakihara, S. Kimura, Y. Kurebayashi, M. Hirai, M. Yohda, and S. Hasegawa. 2007. Single nucleotide polymorphism genotyping of CYP2C19 using a new automated system. Anal. Biochem. 370:121-123.

Melton, S. L., M. Amiri, G. W. Davis, and W. R. Backus. 1982. Flavor and chemical characteristics of ground beef from grass-, forage-, grain- and grain-finished steers. J. Anim. Sci. 55:7787.

Milanesi, E., L. Nicoloso, and P. Crepaldi. 2008. Stearoyl-CoA desaturase (SCD) gene polymorphism in Italian cattle breeds. J. Anim. Breed. Genet. 125:63-67.

Miyazaki, M., A. Dobrzyn, W. C. Man, K. Chu, H. Sampath, D. B. Westerling, and H. B. Hedrick. 1979. Fatty acid composition of bovine lipids as influenced by diet, sex and anatomical location and relationship to sensory characteristics. J. Anim. Sci. 48:1343-1348.

Oh, D. Y., Y. S. Lee, and J. S. Yeo. 2011. Identification of the SNP (single nucleotide polymorphism) of the stearoyl-CoA desaturase (SCD) associated with unsaturated fatty acid in Hanwoo. Asian-Aust. J. Anim. Sci. 24:757-765.

Oh, D. Y., Y. S. Lee, B. M. La, and J. S. Yeo. 2012. Identification of the SNP (single nucleotide polymorphism) for fatty acid composition associated with beef flavor-related FABP4 (fatty acid binding protein 4) in Korean cattle. Asian-Aust. J. Anim. Sci. 25:913-920.

Ohsaki, H., A. Thnaka, S. Hoashi, S. Sasazaki, K. Oyama, M. Taniguchi, F. Mukai, and H. Mannen. 2009. Effect of SCD and SREBP genotypes on fatty acid composition in adipose tissue of Japanese Black cattle herds. Anim. Sci. J. 80:225-232.

O'Keefe, P. W., G. H. Wellington, L. R. Mattick, and J. R. Stouffer. 1968. Composition of bovine muscle lipids at various carcass locations. J. Food. Sci. 33:188-192.

Paolo, G. 2003. Applied data mining: Statistical methods for business and industry (Statistics in practice. John Wiley \& Sons, England

Paton, C. M., and J. M. Ntambi. 2009. Biochemical and physiological function of stearoyl-CoA desaturase. Am. J. Physiol. Endocrinol. Metab. 297:E28-E37.

Ritchie, M. D., L. W. Hahn, N. Roodi, L. R. Bailey, W. D. Dupont, 
F. F. Parl, and J. H. Moore. 2001. Multifactor-dimensionality reduction reveals high-order interactions among estrogenmetabolism genes in sporadic breast cancer. Am. J. Hum. Genet. 69:138-147.

Scollan, N., J. F. Hocquette, K. Nuernberg, D. Dannenberger, and I. M. A. Richardson. 2006. Innovation in beef production system that enhance the nutritional and health value of beef lipids and their relationship with meat quality. Meat Sci. 74:17-33.

Shin, S. C. 2006. The development of DNA markers related to carcass and meat quality traits in Korean cattle. MS thesis, Sang Ji University.

Smith, S. B., D. K. Lunt, K. Y. Chung, C. B. Choi, R. K. Tume, and M. Zembayashi. 2006. Adiposity, fatty acid composition, and delta-9 desaturase activity during growth in beef cattle. J. Anim. Sci. 77:478-486.

Taniguchi, M., H. Mannen, K. Oyama, Y. Shimakura, A. Oka, H. Watanabe, T. Kojima, M. Komatsu, G. S. Harper, and S. Tsuji. 2004. Differences in stearoyl-CoA desaturase mRNA levels between Japanese Black and Holstein cattle. Livest. Prod. Sci. $87: 215-220$.
Taniguchi, M., T. Utsugi, K. Oyama, H. Mannen, M. Kobayashi, Y. Tanabe, A. Ogino, and S. Tsuji. 2004. Genotype of stearoylCoA desaturase is associated with fatty acid composition in Japanese Black cattle. Mamm Genome. 14:142-148.

Tsuji, S., K. Itoh, S. Sasazaki, H. Mannen, K. Oyama, M. Shojo, and F. Mulai. 2004. An association study using AFLP markers and application to a beef cattle breeding population. Anim. Genent. 35:40-43.

Tsuji, S. 2008. Kobe beef as international brand. Symposium of Gyeungbuk Hanwoo Cluster.

Vreeland, W. N., R. J. Meagher, and A. E. Barron. 2002. Multiplexed, highthroughput genotype by single base extension and endlabeled free solution electrophoresis. Anal. Chem. 74:4328-4333.

Webb, E. C., and H. A. O'Neil. 2008. The animal fat paradox and meat quality. Meat Sci. 80:28-36.

Zhang, S., T. J. Knight, J. M. Reecy, and D. C. Beitz. 2008. DNA polymorphisms in bovine fatty acid synthase are associated with beef fatty acid composition. Anim. Genet. 39:62-70 